Special issue of the 3rd International Conference on Computational and Experimental Science and Engineering (ICCESEN 2016)

\title{
The Usage of Perlitic Pumice from İzmir-Menderes (Turkey) in the Production of Low-Strength Lightweight Concrete
}

\author{
H. CEYlan ${ }^{a *}$ AND S. SARAC ${ }^{b}$ \\ ${ }^{a}$ Suleyman Demirel University, Technical Sciences Vocational School, \\ Department of Construction, Isparta 32260, Turkey \\ ${ }^{b}$ Suleyman Demirel University, Faculty of Engineering, Mining Engineering Department, Isparta 32260, Turkey \\ Lightweight aggregates, used to produce cavity blocks in the construction sector, vary according to their \\ technical properties and thus, technical analyses should be performed on lightweight aggregate specimens. Lig- \\ htweight aggregates, like pumice, are widely employed for the production of construction elements, used as light \\ masonry units. In literature there are studies related to applications of various lightweight aggregates, such as \\ volcanic slag, ignimbrite and expanded clay, in addition to pumice, to produce porous cavity blocks. This study \\ investigates the usability of perlitic pumice formations, present around Menderes, İzmir (Turkey), as lightweight \\ aggregate. Many experiments were conducted to investigate this possibility and to determine the optimum mixing \\ ratios of aggregate. Based on the results, for $10 \%$ of cement by volume, the optimum aggregate mixing ratio was \\ $40 \%$ 0-4 $\mathrm{mm}$ and $60 \%$ 4-8 $\mathrm{mm}$.
}

DOI: 10.12693/APhysPolA.132.667

PACS/topics: 81.05.-Rm, 81.05.-t

\section{Introduction}

Structural members of various types can be produced from lightweight concrete. Cavity blocks, hollow blocks and insulating plates are the most important products among them. Industrial development has been seen in Turkey, especially in the production of cavity blocks [1]. The use of light cavity blocks decreases the weight of multi-storey buildings. Moreover, in Turkey, because heat insulation has become obligatory in buildings, and a mandatory energy performance certificate is required for buildings, the insulating construction elements, such as porous light wall blocks, have become more important. Lightweight aggregates, like pumice, are widely used for the production of construction elements, used as light masonry units. Porous cavity blocks, using pumice, are also called "lightweight concrete masonry blocks".

In literature, there are studies related to the application of various lightweight aggregates, such as volcanic slag, ignimbrite and expanded clay, in addition to pumice, to produce porous cavity blocks $[2,3]$. This study investigates the usability of perlitic pumice formations, present around the district of Menderes in İzmir province, in the production of light cavity blocks, as lightweight aggregates.

Perlitic pumice formations are located in the southern part of Menderes County, the former name of which was Cumaovasi, at a distance of $20 \mathrm{~km}$ from the city center of İzmir. The mining field consists of young volcanic cones formed along fractures. The field has different rock types and a quiet rough morphology with deep valleys to the

\footnotetext{
*corresponding author; e-mail: hakanceylan@sdu.edu.tr
}

west [4]. The depth of ore deposits is between 25 to $90 \mathrm{~m}$. Deposits are lying discontinuously along the Murat Hill and Karadağ for $10 \mathrm{~km}[5]$. Although perlite and pumice bedding stratifications are known to exist, there is also a transitional rock called perlitic pumice.

Perlitic pumice is a natural and porous rock type. This rock, obtained from the zone between perlitic bedding stratifications, shows lightweight aggregate characteristics due to its lightness and porosity. In macroscopic investigations, done on perlitic pumice samples, a spongy and porous structure is observed. The existence of a large and non-uniform porous structure in large aggregate particles has been noted. On the other hand, finesized and non-uniform porous structures are observed in small-sized particles. The most effective component of this acidic rock is $\mathrm{SiO}_{2}$. In macroscopic and microscopic investigations of samples, it shows some characteristics of both the perlite and the pumice, since it is a transitional rock. Therefore, it is named as perlitic pumice [1].

In this study, optimum mixture ratios were determined by casting concrete samples using perlitic pumice components, having different particle size distributions.

\section{Experimental method}

This study has employed specimens of perlitic pumice with the dimensions from 0 to $4 \mathrm{~mm}$ and from 4 to $8 \mathrm{~mm}$, obtained from mineral deposits of Menderes, İzmir. The results of chemical analysis of the perlitic pumice and the cement are shown in Table I. CEM-1 32.5 cement was selected for experiments because the subject of the study is related to production of low-strength, lightweight concrete.

In the research, lightweight concrete specimens were prepared based on the TS 3234 standard [7]. Within this scope, lightweight concrete specimens having 6,8 , 


\section{TABLE I}

Chemical composition of İzmir-Menderes perlitic pumice and composition of the cement [6].

\begin{tabular}{c|c|c}
\hline \hline Component & Perlitic pumice [\%] & Cement [\%] \\
\hline $\mathrm{SiO}_{2}$ & 72.63 & 20.74 \\
$\mathrm{Al}_{2} \mathrm{O}_{3}$ & 12.14 & 4.12 \\
$\mathrm{Fe}_{2} \mathrm{O}_{3}$ & 0.89 & 3.56 \\
$\mathrm{CaO}$ & 0.27 & 64.18 \\
$\mathrm{Na}_{2} \mathrm{O}$ & 1.62 & 0.63 \\
$\mathrm{~K}_{2} \mathrm{O}$ & 5.99 & 0.72 \\
$\mathrm{MgO}$ & 0.01 & 1.59 \\
$\mathrm{TiO}_{2}$ & 0.03 & - \\
$\mathrm{MnO}$ & 0.07 & - \\
$\mathrm{P}_{2} \mathrm{O}_{5}$ & 0.003 & - \\
$\mathrm{Mass} \mathrm{loss}$ & 5.17 & 2.69
\end{tabular}

and $10 \%$ of cement by volume were prepared in the vibration and pressing unit as dry mixtures, by using aggregates at various mixing ratios. Fifteen different concrete mixtures, having five aggregate combinations, were prepared to determine the optimum mixing ratio of fine and coarse aggregates (Table II). Materials were subjected to natural curing after casting and then stored. Dry unit weight and uniaxial compressive strength values were determined after a 28 -day curing process.

TABLE II

Amounts of materials used for $1 \mathrm{~m}^{3}$ of mortar.

\begin{tabular}{|c|c|c|c|c|}
\hline $\begin{array}{l}\text { Mixture } \\
\text { No. }\end{array}$ & $\begin{array}{c}\text { Aggregate } \\
\text { mixing } \\
\text { ratios }\end{array}$ & $\begin{array}{c}0-4 \\
{\left[\mathrm{~kg} / \mathrm{m}^{3}\right]}\end{array}$ & $\begin{array}{c}4-8 \\
{\left[\mathrm{~kg} / \mathrm{m}^{3}\right]}\end{array}$ & $\begin{array}{l}\text { Cement } \\
{\left[\mathrm{kg} / \mathrm{m}^{3}\right]}\end{array}$ \\
\hline $\begin{array}{l}\text { M1 } \\
\text { M2 } \\
\text { M3 }\end{array}$ & $\begin{array}{c}100 \% \\
0 \text { to } 4 \mathrm{~mm}\end{array}$ & $\begin{array}{l}1130 \\
1106 \\
1082\end{array}$ & $\begin{array}{l}- \\
- \\
-\end{array}$ & $\begin{array}{c}78 \\
104 \\
130\end{array}$ \\
\hline $\begin{array}{l}\text { M4 } \\
\text { M5 } \\
\text { M6 }\end{array}$ & $\begin{array}{l}60 \% 0 \text { to } 4 \mathrm{~mm} \\
40 \% 4 \text { to } 8 \mathrm{~mm}\end{array}$ & $\begin{array}{l}678 \\
664 \\
649\end{array}$ & $\begin{array}{l}392 \\
374 \\
366\end{array}$ & $\begin{array}{c}78 \\
104 \\
130\end{array}$ \\
\hline $\begin{array}{l}\text { M7 } \\
\text { M8 } \\
\text { M9 }\end{array}$ & $\begin{array}{l}50 \% 0 \text { to } 4 \mathrm{~mm} \\
50 \% 4 \text { to } 8 \mathrm{~mm}\end{array}$ & $\begin{array}{l}565 \\
553 \\
541 \\
\end{array}$ & $\begin{array}{l}478 \\
468 \\
457\end{array}$ & $\begin{array}{c}78 \\
104 \\
130\end{array}$ \\
\hline $\begin{array}{l}\text { M10 } \\
\text { M11 } \\
\text { M12 }\end{array}$ & $\begin{array}{l}40 \% 0 \text { to } 4 \mathrm{~mm} \\
60 \% 4 \text { to } 8 \mathrm{~mm}\end{array}$ & $\begin{array}{l}452 \\
442 \\
473\end{array}$ & $\begin{array}{l}573 \\
561 \\
549 \\
\end{array}$ & $\begin{array}{c}78 \\
104 \\
130\end{array}$ \\
\hline $\begin{array}{l}\text { M13 } \\
\text { M14 } \\
\text { M15 }\end{array}$ & $\begin{array}{c}100 \% \\
4 \text { to } 8 \mathrm{~mm}\end{array}$ & $\begin{array}{l}- \\
- \\
-\end{array}$ & $\begin{array}{l}955 \\
935 \\
914\end{array}$ & $\begin{array}{c}78 \\
104 \\
130\end{array}$ \\
\hline
\end{tabular}

\section{Results and discussion}

For low-strength, porous cavity block production, lightweight concrete specimens having 6,8 , and $10 \%$ of cement by volume were prepared using perlitic pumice aggregates with particle size of $0-4 \mathrm{~mm}$ and $4-8 \mathrm{~mm}$. Dry unit weight, uniaxial compressive strength and water absorption values of the samples of 15 mixing groups, after twenty eight days of curing, are shown in Table III. Variation of the uniaxial compressive strength and dry unit weight with the amount of cement and for different aggregate mixing combinations are shown in Figs. 1 and 2.

TABLE III

Parameters of lightweight concrete specimens for different aggregate mixing ratios.

\begin{tabular}{c|c|c|c|c}
\hline \hline $\begin{array}{c}\text { Specimen } \\
\text { No. }\end{array}$ & $\begin{array}{c}\text { Dry } \\
\text { unit } \\
\text { weight } \\
{\left[\mathrm{kg} / \mathrm{m}^{3}\right]}\end{array}$ & $\begin{array}{c}\text { Uniaxial } \\
\text { compressive } \\
\text { strength } \\
{\left[\mathrm{kg} / \mathrm{cm}^{2}\right]}\end{array}$ & $\begin{array}{c}\text { Water } \\
\text { absorption } \\
{[\%]}\end{array}$ & $\begin{array}{c}\text { Aggregate } \\
\text { and cement } \\
\text { mixing ratios }\end{array}$ \\
\hline M1 & 1288 & 3.60 & 18.05 & $100 \% 0-4 \mathrm{~mm}$ \\
M2 & 1379 & 16.50 & 18.69 & $6 \%, 8 \%, 10 \% \mathrm{PC}^{*}$ \\
M3 & 1478 & 24.65 & 16.57 & \\
\hline M4 & 1356 & 8.15 & 14.60 & $60 \% 0-4 \mathrm{~mm}$ \\
M5 & 1342 & 9.80 & 16.16 & $40 \% 4-8 \mathrm{~mm}$ \\
M6 & 1397 & 14.75 & 14.53 & $6 \%, 8 \%, 10 \% \mathrm{PC}$ \\
\hline M7 & 1367 & 6.80 & 15.65 & $\% 500-4 \mathrm{~mm}$ \\
M8 & 1447 & 19.45 & 14.53 & $\% 504-8 \mathrm{~mm}$ \\
M9 & 1406 & 20.80 & 12.73 & $6 \%, 8 \%, 10 \% \mathrm{PC}$ \\
\hline M10 & 1349 & 5.80 & 14.01 & $40 \% 0-4 \mathrm{~mm}$ \\
M11 & 1416 & 14.25 & 13.43 & $60 \% 4-8 \mathrm{~mm}$ \\
M12 & 1471 & 25.55 & 13.56 & $6 \%, 8 \%, 10 \% \mathrm{PC}$ \\
\hline M13 & 1364 & 7.25 & 14.29 & $100 \% 4-8 \mathrm{~mm}$ \\
M14 & 1366 & 7.10 & 13.49 & $6 \%, 8 \%, 10 \% \mathrm{PC}$ \\
M15 & 1336 & 14.40 & 12.58 & \\
\hline PC (Port & & &
\end{tabular}

PC (Portland cement)

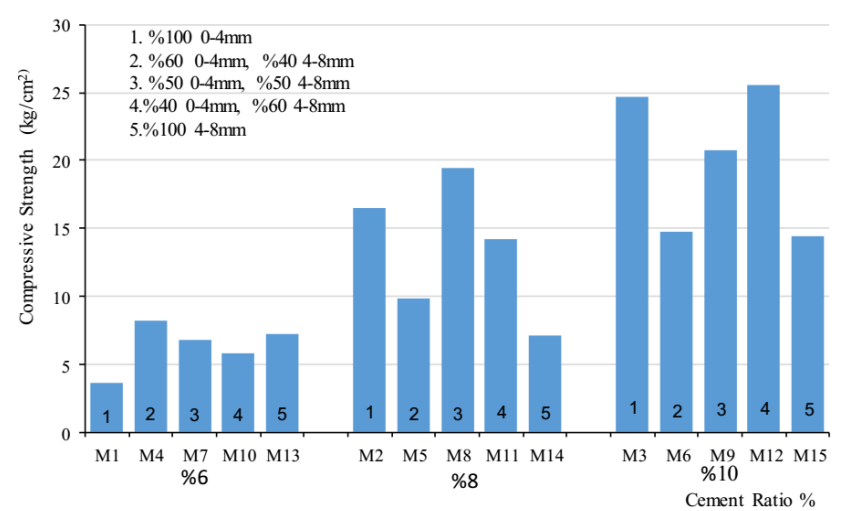

Fig. 1. Uniaxial compressive strength for different combinations of cement amount and different aggregate mixing ratios.

There are two factors of importance for porous masonry blocks: uniaxial compressive strength and dry unit weight. Based on the TS EN-771-3 standard [8], an arbitrary limit value is specified for masonry units intended to be used as non-load-bearing wall members. However, in practice, 28-day compressive strength values of masonry wall members should be $25 \mathrm{~kg} / \mathrm{cm}^{2}$ and unit weight values should be between 600 to $800 \mathrm{~kg} / \mathrm{m}^{3}$ [2].

After examining the uniaxial compressive strength values, the highest strength value in mixtures with $6 \%$ of Portland cement (PC), in volume, was $8.15 \mathrm{~kg} / \mathrm{cm}^{2}$. This value was achieved in the mixture of "60\% $0-4 \mathrm{~mm}$ and $40 \%$ 4-8 mm" aggregates. 


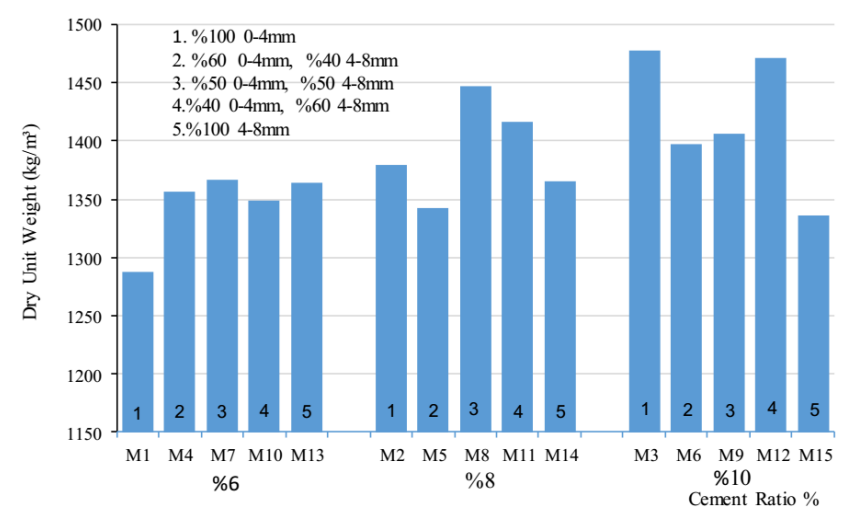

Fig. 2. Dry unit weight for different combinations of cement amount and different aggregate mixing ratios.

The highest uniaxial compressive strength value in mixtures with $8 \%$ of PC, by volume, was $19.45 \mathrm{~kg} / \mathrm{cm}^{2}$. It was achieved in the mixture with aggregate combination of " $50 \%$ 0-4 mm and 50\% 4-8 mm".

The highest uniaxial compressive strength value in mixtures with $10 \%$ of PC, by volume, was $25.55 \mathrm{~kg} / \mathrm{cm}^{2}$. It was achieved in the mixture with aggregate combination of " $40 \%$ 0-4 mm and $60 \%$ 4-8 $\mathrm{mm}$ ".

Although low-strength values were obtained at the end of the study, the compressive strength value of $25.55 \mathrm{~kg} / \mathrm{cm}^{2}$, obtained in the mixture M12 is appropriate for production of light wall blocks. Based on these results, for $10 \%$ of cement by volume, it can be seen that the optimum aggregate mixing ratio was " $40 \%$ 0-4 mm and $60 \%$ 4-8 $\mathrm{mm} "$.

It was found that the dry unit weight values of lightweight concrete specimens were between $1288 \mathrm{~kg} / \mathrm{m}^{3}$ and $1478 \mathrm{~kg} / \mathrm{m}^{3}$. Both values were obtained in the " $100 \% 0$ to $4 \mathrm{~mm}$ " mixture. The lower limit was obtained at $6 \%$ of cement, by volume, while the upper limit was obtained at $10 \%$ of cement, by volume. Dry unit weight values were within the standard values and are determined to be in the D 1.4 and D 1.6 group, based on the classification specified in the TS EN 206-1 standard [9].

\section{Conclusions}

Low-strength values were obtained in the study because of the use of 6,8 , and $10 \%$ of cement by volume and because of the employed CEM-1 32.5 type of cement. Despite of using very small cement amounts, the compressive strength value of $25.55 \mathrm{~kg} / \mathrm{cm}^{2}$, obtained in the mixture M12 is appropriate for the production of pumice concrete unreinforced cavity blocks for light structural members. The highest strength value was obtained from the " $10 \%$ of cement by volume, $40 \% 0$ to $4 \mathrm{~mm}$ and $60 \%$ 4 to $8 \mathrm{~mm}$ " combination of aggregates.

\section{References}

[1] H. Ceylan, Ph.D. Thesis, SDU Graduate School of Natural and Applied Sciences, 2005.

[2] S. Demirdă̆, L. Gündüz, in: 3rd Aggregate Symposium Proceedings Book, İstanbul 2003, p. 51.

[3] N. Şapcı, L. Gündüz, F. Yağmurlu, Pamukkale Univ. Engin. Sci. J. 20, 63 (2014).

[4] Ü. Ürün, Ms. Sci. Thesis, DEU Graduate School of Natural and Applied Sciences, 2004.

[5] DPT, Construction Materials III (Pumice-PerliteVermiculite-Phlogopite-Expansive Clays) Working Group Report, Mining Specialization Commission Industrial Raw Materials Sub-Commission Report, Ankara 2001.

[6] Anonymous, IZOLAKUM, Production Catalogue, Pumice Export Mining Ind. Tra. I. C., İzmir 2001.

[7] TS 3234, Pumice Concrete Construction Rules: mixing calculation and experimental methods, Turkish Standards Institute, Ankara 1978.

[8] TS EN 771-3, Masonry Units-Properties - Chapter 3: Concrete masonry units (with dense and light aggregate), Turkish Standards Institute, Ankara 2015.

[9] TS EN 206-1, Concrete - Chapter 1: Property, Performance, Production and Conformity, Turkish Standards Institute, Ankara 2002. 